Review Article

www.ijrap.net

\title{
ETIOPATHOGENESIS OF HYPERTENSION IN AYURVEDA
}

Rajashekhar V. Sanapeti*, Sreelakshmi Chaganti

Dept of PG studies in Panchakarma, KLEU's BMK Ayurveda Mahavidyalaya \& Hospital, Belgaum, Karnataka, India

Received on: 10/08/12 Revised on: 14/10/12 Accepted on: 09/11/12

\author{
*Corresponding author \\ E-mail: rajashekharpk@gmail.com \\ DOI: 10.7897/2277-4343.03618 \\ Published by Moksha Publishing House. Website www.mokshaph.com \\ All rights reserved.
}

\section{ABSTRACT}

Hypertension is prevalent disorder with $33.5 \%$, accounting for $6 \%$ of deaths worldwide. Various scattered references are present in Ayurvedic literature depicting Hypertension disease. Shonita dushti can be correlated with this particular disease. The detailed explanation of its nidana panchaka has been elaborated in terms of Hypertension. Here is an effort made to establish the etiopathogenesis of Hypertension in Ayurveda.

Key words: Hypertension, Shonita dushti, Blood Pressure

\section{INTRODUCTION}

Hypertension (High blood pressure) is an elevated arterial pressure measured with the help of an instrument "Sphygmomanometer" when the levels are > 140/90 mm of Hg. It is a major risk factor for stroke, myocardial infarction, heart failure and peripheral arterial disease. Prevalence of Hypertension is $33.5 \%$ and risk increases with age above 60 years. It has been estimated that hypertension accounts for $6 \%$ of deaths worldwide. Both environmental and genetic factors may contribute to regional and racial variations of blood pressure. Obesity and weight gain are strong, independent risk factors for Hypertension. Among populations, hypertension prevalence is related to dietary $\mathrm{NaCl}$ intake. Additional environmental factors that may contribute to hypertension include alcohol consumption, psychological stress and low levels of physical activity. Even though Hypertension is diagnosed instrumentally, symptoms will also manifest in sustained Hypertension which include headache, giddiness, palpitation and fatigability ${ }^{1}$. In Ayurveda, while explaining Shonita dushti in Vidhishonitiya adhdhyaya many causative factors are elicited among those ati lavana sevana, madya, sura pana, ati snigdha bhojana and ati chinta, shoka etc. manasika bhavas which are similar to the etiological factors of Hypertension. Shonita dushti will give rise to many manifestations which include shirashoola, bhrama, klama ${ }^{2}$ etc resemble Hypertension symptoms.

\section{Regulation of Blood Pressure in Ayurveda}

The regulation of Blood pressure is carried by Myocardial contractility that pump the heart continuously and ejects the blood from ventricles into vessels. Normal heart rate and volume of blood helps in maintaining normal Blood pressure. In Ayurveda regulation of Blood pressure can be understood by functions of Prana vayu, Vyana Vayu, Sadhaka Pitta, Avalambaka Kapha, and Rakta Dhatu which are situated in Hridaya.

Prana vayu: Prana vayu situated in murdha $^{3}$ performs the functions like hridaya dharana, buddhi, indriya dharana ${ }^{4}$. Here hridaya dharana could be viewed as neural stimulation of Cardio-vascular centre in the medulla oblongata that controls the functions of the heart. CV centre regulates heart rate, contractility of ventricles and blood vessel diameter through which it regulates the blood pressure ${ }^{5}$. Hridaya dharana function specifies influence of Prana vayu on heart functions via vyana vayu that regulates normal myocardial activities. This mechanism can be considered as neural regulation of blood pressure.

Vyana vayu: Vyana vayu situated in hridaya ${ }^{6}$ performs the functions like-Rasadi samvahana, Prasarana, Akunchana, Gati, Asrik sravana? ${ }^{7}$ Nyaya chandrika commentary explains rasadi samvahana as rasa-rakta samvahana. Prasarana, Akunchana could be viewed with respect to contraction and relaxation of heart. Gati as the force of blood flow. Hence Vyana vayu in its normal state performs contraction and relaxation of the heart and propels the blood from the heart to the body tissues and the blood pressure remains in normal limits.

Sadhaka pitta: Sadhaka pitta situated in Hridaya responsible for Buddhi, Medha, Utsaha ${ }^{8}$ and helps to keep away Tama and raja guna which hampers normal functions of Manas. As Hridaya is the seat of manas, in good status of mental health the Cardiac functions are optimum and blood pressure will be in normal limits. Any psychological disturbance hampers the normal functions of Sadhaka pitta w.r.t increase in raja guna that aggrevates the vyana vata resulting in variations of Cardio-vascular functions which ensues in exaggerated contractility of heart that increases forceful expulsion of blood resulting into high blood pressure.

Avalambaka kapha: Avalambaka kapha situated in urah sthana performs Avalambana of hridaya. Hemadri commenting on avalmabhana said as 'Hridaya samarthya Karoti'. Avalambaka kapha gives strength to the cardiac muscle tissue for proper pumping action which results in ejecting blood to body tissues through vessels. Hence samyavastha of Avalambaka kapha helps in maintaining normal blood pressure. 


\section{Etiological Factors (Nidana)}

Essential hypertension is idiopathic where exact etiology of the rise in blood pressure is not yet clear, although few pre-disposing factors have the strongest association with blood pressure. Excessive salt intake, excessive alcohol intake, fatty diet, psychological stress is elicited as the causative factors of Hypertension ${ }^{9}$. In parallel ati lavana sevana, madya, sura pana, ati snigdha bhojana and chinta, shoka, bhaya are nidanas of Shonita dusti ${ }^{10}$ which could be viewed w.r.t. Hypertension.

Excessive Salt intake (Ati lavana sevana): Excessive intake of salt for a longer duration is suspected to have an etiological influence on the blood pressure. Salt more than $10 \mathrm{gms} /$ day leads to renal retention of salt and water which in turn increases the plasma and extravascular fluid volume that keeps the circulatory volume higher than it should be, exerting excess fluid pressure on blood vessel walls. These walls react to this stress by thickening and narrowing, leaving less space for the fluid raising "resistance" and requiring higher pressure to move blood to the organs. The heart has to pump against this high pressure system that leads to High blood pressure ${ }^{11}$. Vagbhatta has described the qualities of lavana rasa as vishyandi, tikshana and ushna. When ati lavana is consumed in diet it leads to pitta and shonita vitiation along with increase in the quantity of rakta ${ }^{12}$. Lavana rasa is formed with Jala and Agni Mahabhuta and one of the function described as kledana which can be compared with retention of sodium ions in the tissues and increased quantity of rakta can be correlated with the excessive blood volume which may lead to increase in the blood pressure.

Excessive Alcohol Intake (Ati madyapana): Excessive intake of Alcohol for the longer period damages cardiac muscle tissue. As a result cardiac pump action becomes less active, more blood remains in ventricles at the end of each cardiac cycle and gradually the end diastolic volume (preload) increases. Initially this increased preload may promote increased force of contraction for compensation. This increased force of contraction results into increased blood pressure ${ }^{13}$.

Ushana, tikshna, sukshma, vishada, ruksha, ashukari, vyavayi, vikashi are ten qualities of madya which are exactly opposite to the qualities of $\mathrm{Oja}^{14}$. Ushana, tikshna guna provoke pitta dosha and shonita dusti. Laghu guna of madhya aggravate vata dosha. Ultimately Oja kshaya occur and Hridaya gets involved being the seat of Oja. Hridayashrita Vyana vayu, Sadhaka pitta, Avalambaka kapha are also get affected. Among the causes of sonita dushti Surapana is also described. This shonita dusti inturn vitiates avalambaka kapha w.r.t kapha kshaya that weakens the function of upachaya of Hridaya mamsapeshi, resulting weak pumping action of heart which results in increase end diastolic volume. Also vitiates the vyana vayu w.r.t vridhdhi resulting aggravated contractility of heart to compensate the extra volume which ultimately leads into increased arterial blood pressure.

Fatty Diet (Snigdha bhojana): There is positive corelation between fatty food habits and arterial blood pressure. The high intake of dietary fats stimulates reabsorption of cholesterol containing bile back into blood. Also the saturated fats are broken down in the body, the liver uses some of the break down products to produce cholesterol. High blood cholesterol promotes the growth of fatty plaques that build up in the wall of arteries. As the plaque enlarges the passageway for blood flow narrows and results in increased vascular resistance leads to increased arterial blood pressure ${ }^{15}$.

In etiopathogenesis of Shonita dusti, excessive intake of snigdha, guru ahara with day sleep is explained. Ati Snigdha, Guru Ahara causes Jatharagni Vaigunya and Medodhatvagni mandhya leads to production of Ama (apakwa rasadhatu) and Apakva Medovriddhi. This Apakva meda and rasa when deposits in Rasavaha Srotas may leads to Dhamani Pratichaya ${ }^{16}$ (Atherosclerosis), which may be a responsible factor of High Blood pressure.

Stress (manovighata): There is a clear relation between emotional stress and temporary rise in blood pressure. The mechanism by which mind affects arterial pressure could be either by a central influence on sympathetic efferent neurons which ultimately leads to increased arterial blood pressure ${ }^{17}$

In Ayurveda ati chinta, shoka, bhaya are said to be causitive factors of shonita dusti. These Manasika Bhavas Vitiate Manas via Raja and Tama. As a result, prana vayu gets prakopa and vitiates hridaya which is the seat of manas, resulting into Hrid-drava, an increased cardiac output ultimately manifesting in increased blood pressure. Age: Older age people tend to have higher blood pressure than young people. Studies have demonstrated that blood pressure rise with advancing age. The mechanism is, the decline of plasma renin and catacholamines with age. It is also secondary to structural thickening and degenerative changes in arteries and arterioles. Due to the thickening of vessel wall as arteriosclerosis leads to decrease in elasticity results increased resistance that tends to cause increase in blood pressure ${ }^{18}$.

Acharya Sushruta has mentioned that the nutrient materials can not nourish the body which has under gone changes due to age ${ }^{19}$. Old age is Vatadosha pradhana vaya. Physiological aggravation of Vata with its Ruksha, Khara, Daruna, Sheeta Gunas may cause Sankocha and Kathinya of the vessels. Poor nourishment of dhamanis results in reduction of the lumen of the arteries that raise the blood pressure.

\section{Pathogenesis of Blood Pressure in Ayurveda}

Ati lavana sevana, madyapana, snigdha bhojana with diva shayana and mano vigatha leads to vitiation of Shonita. But Shonita being dhatu is not capable of vitiating doshas independently. The doshas present in the Shonita which are involved indirectly in the manifestation of high blood pressure.

The over use of salt, alcohol vitiates the Sadhaka pitta and Shonita. Sedentary habits vitiate the Avalambaka kapha and psychological stress induces vitiation of Prana vayu. Initially Prana vayu gets prakopa. Since Prana vayu has influence on hirdaya, vitiates Hridaya and its residing components like Vyana vayu, Sadhaka pitta, Avalambaka kapha. Shonita is also involved as it is located in hridaya. Prakupita Avalambaka kapha induces exaggerated contractility of the heart, while aggrevted Vyana vayu 
leads increased gati, the force of ejection of blood from Hridaya. These events result into forceful expulsion of blood through dhamanis, ultimately leading into increased resistance in vessels ensuing High blood pressure.

\section{Samprapti Ghatakas}

Doshas : Prana, Vyana vayu, Sadhaka Pitta, Avalambaka Kapha

Dushyas: Rakta, rasa, meda

Agni : Jatharagni-Dhatwagnimandya

Aama : Rasagata

Srotas : Raktavaha, Rasavaha \& Manovaha

Srotodushti-Prakara : Sanga type of srotorodha

UdbhavaSthana : Hridaya, Dhamani

Adhisthana : Mano-daihika (Sira, Dhamani,

Srotas)

Sanchara-sthana : Sarva Sharir

Rogamarga : Madhyama Rogamarga

\section{Lakshanas}

Hypertension is asymptomatic in most cases. But the symptoms can be seen in accelerated hypertension or sustained hypertension like - Headache, Dizziness, Palpitation and Fatigability.

Headache: Headache usually in the early morning hours is one of the symptoms of hypertension. It is located in the occipital region that subsides in the later hours of the day. Shiroruk is one of the lakshanas of shonita dusti explained in vidhisonitiya adhya ${ }^{20}$

Dizziness: Dizziness transient or persistent is presentation of hypertension. Parallel to this, Bhrama is the feature of shonita dusti. Here the dosha involved are Pitta, Vata, and Rajas $^{21}$. The chala guna of vayu becomes more dominant due to vitiated raja dosha and along with pitta results into bhrama.

Palpitation: Tachycardia representing the palpitation is the symptom of Hypertension. Acharya Gangadhara has clearly mentioned Hrid-drava means increased Gati of Hridaya. So while describing the symptoms of Rasa kshaya, Acharya Charaka mentioned "Hridayam Tamyati" 22 the exaggerated contractility of heart. Here, Vyana vayu is aggravated with its Chala Guna resulting in Hridadravata.

Fatigability: Easy fatigability is one of the feature of Hypertension. Without any physical or mental work the feeling of tiredness of the body and mind is called Klama $^{23}$. Charaka has mentioned Klama under Shonitaja Dusti.

\section{CONCLUSION}

Normal regulation of blood pressure, etiological factors and patho-physiology of Hypertension resembles with Shonita dushti nidana, samprapti and lakshanas along with the involvement of Prana vayu, vyana vayu, sadhaka pitta and avalambaka kapha. Hence Shonita dushti can be correlated with Hypertension

\section{REFERENCES}

1. Harrison, Principles of Internal Medicine, Naomi DL. Fisher, Gordon H. Williams, 16th edition, p.1463-1464

2. Agnivesha, Charaka samhita, Dipika commentary of Chakrapanidatta, edited by Vaidya Jadavaji Trikamaji Acharya, 5th edition, Varanasi Chaukhamba publications, 2001, p 124

3. Agnivesha, Charaka samhita, Dipika commentary of Chakrapanidatta, edited by Vaidya Jadavaji Trikamaji Acharya, 5th edition, Varanasi Chaukhamba publications, 2001, p.616

4. Vagbhata, Astanga Hridayam, commentaries of Arunadatta and Hemadri, edited by Bhishagacharya Harishastri Paradakara vaidya , 9th edition, Chaukhamba publications 2002, p.193

5. Tortora, Principles of Anatomy and Physiology, Gerald J Tortora and Sandra Reynolds Grabowski, 10th edition, p.709

6. Vagbhata, Astanga Hridayam, commentaries of Arunadatta and Hemadri, edited by Bhishagacharya Harishastri Paradakara vaidya , 9th edition, Chaukhamba publications 2002, p.193

7. Susruta, Nibandha sangraha commentary by Dalhana, edited by Vaidya Jadavaji Trikamaji Acharya, 7th edition, Chaukhamba publications 2002, p.260

8. Vagbhata, Astanga Hridayam, commentaries of Arunadatta and Hemadri, edited by Bhishagacharya Harishastri Paradakara vaidya , 9th edition, Varanasi Chaukhamba publications 2002, p.194

9. Harrison, Principles of Internal Medicine. Naomi D.L. Fisher, Gordon H. Williams, 16th edition, p.1463-1464

10. Agnivesha, Charaka samhita, Dipika commentary of Chakrapanidatta, edited by Vaidya Jadavaji Trikamaji Acharya, 5th edition, Varanasi Chaukhamba publications 2001, p 124

11. Cushman WC. The burden of uncontrolled hypertension: morbidity and mortality associated with disease progression. J Clin Hypertens (Greenwich) 2003;5:14- 22 http://dx.doi.org/10.1111/j.15246175.2003.02464.x

12. Agnivesha, Charaka samhita Dipika commentary of Chakrapanidatta, edited by Vaidya Jadavaji Trikamaji Acharya, 5th edition, Varanasi Chaukhamba publications 2001, p.144

13. ABC of Hypertension, edited by Eoin O' Brien; D. Gareth; Beevers; Hpward. J. Marshall, BMJ Publication, 1995, 3rd edition, p. 58

14. Susruta, Nibandha sangraha commentary by Dalhana, edited by Vaidya Jadavaji Trikamaji Acharya, 7th edition, Chaukhamba publications 2002, p741

15. Tortora, Principles of Anatomy and Physiology, Gerald J Tortora and Sandra Reynolds Grabowski, 10th edition, p.708

16. Agnivesha, Charaka samhita, Dipika commentary of Chakrapanidatta, edited by Vaidya Jadavaji Trikamaji Acharya, 5th edition, Varanasi Chaukhamba publications 2001, p.116

17. Price, Text Book of Medicine, by Sir Ronald Bodley Scott; Oxford Publication, 12th edition, p.813

18. Price, Text Book of Medicine, by Sir Ronald Bodley Scott; Oxford Publication, 12th edition, p.814

19. Susruta, Nibandha sangraha commentary by Dalhana, edited by Vaidya Jadavaji Trikamaji Acharya, 7th edition, Chaukhamba publications, 2002, p.64

20. Agnivesha, Charaka samhita, Dipika commentary of Chakrapanidatta, edited by Vaidya Jadavaji Trikamaji Acharya, 5th edition, Varanasi Chaukhamba publications 2001, p.124

21. Susruta, Nibandha sangraha commentary by Dalhana, edited by Vaidya Jadavaji Trikamaji Acharya, 7th edition, Chaukhamba publications, 2002, p.360

22. Agnivesha, Charaka samhita Dipika commentary of Chakrapanidatta, edited by Vaidya Jadavaji Trikamaji Acharya, 5th edition, Varanasi Chaukhamba publications 2001, p.103

23. Susruta, Nibandha sangraha commentary by Dalhana, edited by Vaidya Jadavaji Trikamaji Acharya, 7th edition, Chaukhamba publications, 2002, p.360

Cite this article as:

Rajashekhar V. Sanapeti, Sreelakshmi Chaganti. Etiopathogenesis of hypertension in Ayurveda. Int. J. Res. Ayur. Pharm. 2012; 3(6):786-788 